\title{
3. ПИСЬМЕННОСТЬ
}

DOI: 10.31168/2618-8597.2019.15.19

\author{
Robert Greenberg (Auckland)
}

\section{The Communicative VAlue of SCRIPTS: \\ The Changing Status of Cyrillic IN THE FoRMER YugOSLAVIA}

In this contribution, I examine the changing status of the Cyrillic script in the former Yugoslavia, beginning in the nineteenth century and concluding with the Yugoslav successor states. I consider both the symbolic and communicative functions of the script and focus in particular on the use of the Cyrillic script in the new Montenegrin and Serbian standard languages that have emerged from the once joint Serbo-Croatian language. My focus is on how Cyrillic is promoted in areas in which Serbs make a significant portion of the population, including in Eastern Slavonia (Croatia), Republika Srpska, and Montenegro.

While the status of the Cyrillic script is stable in Macedonia, it is less clear in the areas of the former Serbo-Croatian. The Constitution of the Federal Republic of Yugoslavia from 1992 favored the Cyrillic script, but both the Latin and Cyrillic scripts have long been in competition in the Republic of Serbia. By contrast, in the neighboring successor states, the local Serb population has worked to increase the use of Cyrillic as a primary means of communication, and numerous attempts have been made to secure official status for the Cyrillic script. I analyse these occurrences and examples and attempt to provide conclusions regarding the future status of Cyrillic in the region.

The starting point for my analysis will be the Vukovian reforms in the first half of the nineteenth century and the principle of creating a writing system that reflects the vernacular language rather than a more artificial lit- 
erary standard. I will then discuss proposals related to the unity of Serbian and Croatian including the proposal from 1913 for Serbs to jettison Cyrillic and for Croats to give up the ijekavian pronunciation. The historical overview will then shift to the post-war period when standard Macedonian orthography is standardized and the joint Serbo-Croatian is proclaimed as the common language of Serbs, Croats, and Montengrins (1954). The following period is one in which the status of Cyrillic is perceived by many in Serbian literary and intellectual circles as being threatened with the spread of the Latin script in Belgrade in the post-1954 period.

After Yugoslavia's collapse in 1991, I then look at the efforts among Serbs in the various Yugoslav successor states to re-assert the symbolic and communicative functions of Cyrillic. These efforts are documented based on media reports from Balkan Insight that document movements to introduce bi-scriptual signs in Eastern Croatia (Vukovar in particular), and in the schools of the entity of Republika Srpska in Bosnia and Herzegovina. I also look at the debates over Cyrillic in Montenegro and Kosovo, and compare the status of Cyrillic in the former Serbo-Croatian speaking territories with that of Cyrillic in neighboring Macedonia. I suggest that in areas where Serbs are no longer a majority, the symbolic function of the Cyrillic script has taken precedence over the communicative function, and that increasingly Cyrillic serves as a marker of Serbian Orthodox identity. 